\title{
Standardize and Develop a Complete Meal as a Nutri-Spro Powder for Nutrition of Children
}

\author{
Dr. Swati .D.Shende (Nakhale) ${ }^{* 1}$, Samruddhi Bhaskar Zoting ${ }^{2}$ \\ ${ }^{1}$ Principal, Indian Institute of Food Science and Technology, Aurangabad \\ ${ }^{2}$ Student of M. Sc.Clinical Nutrition and Dietetics Indian Institute of Food Science and Technology, Aurangabad
}

\begin{abstract}
While weight gain in children is a primary concern for most Indian mother's it is important to remember that your name should be insure the balance diet which provide all the nutrition your child needs to grow this will automatically help the child attend on healthy weight a diet also ensure that they get enough nutrient, various vitamins and all the minerals that are required for the overall development of the brain and physics. According to the findings in this study, malnutrition is highly prevalent in the all socioeconomic group 's children 's. There are many reasons as to why the prevalence is evident and will continue in that some factors such as low levels of maternal education, knowledge of nutrition and proper cooking methods and influence a lot on food choices for child feeding The better nutritional profile of under-fives of educated mothers indicates that right to have education and knowledge of proper nutrition is missing among them. It was concluded that nutri-spro powder was shown effective changes on overall growth and development of children and it may be effective if the expecting mother was introduced in her diet from second trimester.
\end{abstract}

Keywords — Early Age Children; Nutri-Spro Powder; Nutrition Education; Malnutrition

\section{Introduction}

Children are the future of the society. Hence to insure sound foundation and secure future of any society, health and nutrition needs protection. The school age period is nutritionally significant because it is the prime to build the body stores of nutrients in preparation for rapid growth of adolescence.(WHO, 2014).

Nutrition-related policies can be implemented at family, local, regional, and national level and at different sectors such as schools, health care, economics, mass media, food environment, etc. (Willett, W 2013 and Mirjana Gurinović 2016) Nature and nurture both contribute to the growth and development of children. Although what's endowed by nature is constant, nurture makes all the difference and here are the factors affecting child growth and development.

Nutritional inadequacies will result in the hampering of the development of the body. Future of the country is determined by the growing generations. It is the health status of the children in any country that stand for the health status of people of that country. Since, this generation is going to be the future productive citizens, they should be healthy enough to make use of the full potential of their productive age.

Community based preventive measures should be taken to alleviate malnutrition. Health education to the parents, especially to the mothers on dietary practices like feeding with healthy foods in terms of quantity and quality should be given. (Anuradha R et.al 2014).

\section{Objectives}

- To investigate the children with the problem of slow Or Poor weight gain and their dietary habits and Lifestyle pattern (6 month's-10yrs).

- To developed and standardised nutri -spro powder.3) To assess the outcome of those children after dietary and Lifestyle modifications.

\section{Material and Methods}

Research approach in this study was descriptive exploratory survey descriptive research studies are those which are concerned with describing the characteristics of the 6 months to 10 years children in Aurangabad. Total 40 samples was randomly selected to see the impact of NutriSpro powder and study the assessment of nutritional status and dietary intake of 6 months to 10 years children. Nutrition education was conducted during council ling in which importance of good nutrition and hazards of junk food along with personal hygiene was explained. Information related the importance of milk, green vegetables and other vegetables, fruits were given. Nutritional status was assessed with the help of anthropometric indices. Tabulated data was analysed with the help of descriptive statistics such as mean, standard deviation and paired T test was applied.

\section{Nutri-Spro Powder}

Nutri- spro powder was rich in almost all essential nutrients. Lots of health benefits are specified such as it 
will helpful to maintain the growth in children's, boost brain development, increased immunity and improve bone health of your child as well.

\subsection{Importance of Nutri-Spro Powder in Babies Weight Gain}

While weight gain in children is primary concern for most Indian mothers .It is important to remember that your aim should be to ensure a balance diet which provides all the nutrition your child needs to grow, Nutri-Spro powder supply a healthy and balance diet. Nutri-Spro powder ensured to get enough nutrients various vitamins and all the minerals that required for the overall development of their brain and physique Nutri-Spro powder is a blend of rice, nuts, oats, sprouted pulses and ragi Sprouting help increase the nutritional value of the grains.

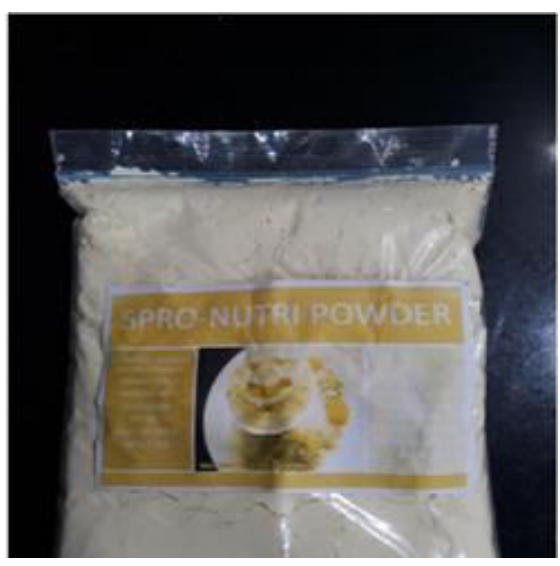

Fig.1: Packaging of nutri-spro powder

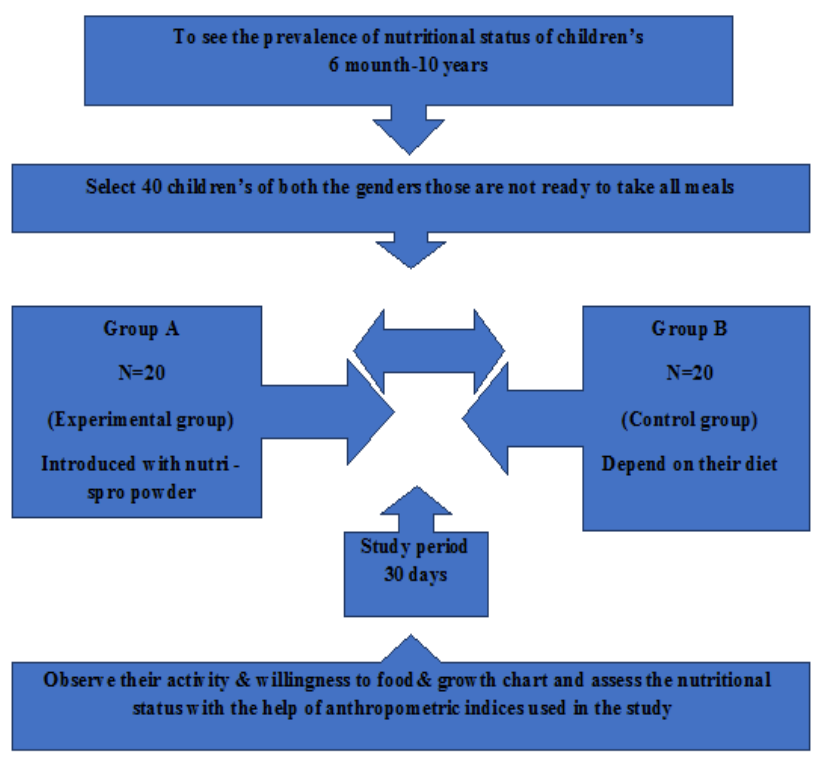

Fig.2: Protocol of the study

\section{Result and Discussion}

The result provides factual statement of observations supported by statistics, tables and graph derived fromthe analysis of the data recorded during the experimentation. The result is presented in logical order in light of the objectives of the study.

Table 1: Demographic Socioeconomic Characteristics $(\mathrm{N}=100)$

\begin{tabular}{|c|c|c|c|}
\hline Factor & Male & $\begin{array}{c}\text { Frequenc } \\
\mathbf{y}\end{array}$ & Percent \\
\hline \multirow{2}{*}{ GENDER } & 20 & 28.57 \\
\hline \multirow{2}{*}{ AGE(YEARS) } & $\begin{array}{c}\text { Mean } \\
\text { (min-Max) }\end{array}$ & $31.95-33$ & 71.42 \\
\hline \multirow{2}{*}{ RELATIONSHIP } & Parent & 62 & 88.57 \\
\cline { 2 - 4 } & Others & 8 & 11.42 \\
\hline HIGHEST & Non formal & No & \\
\cline { 2 - 4 } & Formal & 70 & 100 \\
\hline \multirow{2}{*}{$\begin{array}{c}\text { MARITAL } \\
\text { STATUS }\end{array}$} & Married & 70 & 100 \\
\cline { 2 - 4 } & Unmarried & No & - \\
\cline { 2 - 4 } & Single & No & - \\
\hline INCOME & $\begin{array}{c}\text { Mean (min- } \\
\text { Max) }\end{array}$ & $70,000-$ & \\
\hline INCOME SOURCE & Husband & 60,000 & 85.71 \\
\hline & Casual wages & No & - \\
\hline & Own business & 10 & 14.28 \\
\hline & & & \\
\hline
\end{tabular}

Table 2 stated that mean dietary intake of children's from 6 Months to 10 years group. The food stuff of cereals mean is $95.12 \mathrm{Kcals} /$ day and the recommended value is 195. Likewise pulses $31 \mathrm{gm} /$ day and RDA is 45 , roots \& tubers is $69.75 \mathrm{gm} /$ day and RDA is 87.5 , green leafy vegetables mean intake calculated is 61.75 and RDA is 75 .

Table 2: Mean dietary recall of children's

\begin{tabular}{|c|c|c|c|}
\hline Food Groups & $\begin{array}{c}\text { Mean food } \\
\text { intake }\end{array}$ & RDA & $\begin{array}{c}\text { PAIR T } \\
\text { TEST }\end{array}$ \\
\hline Cereals \& millets & 95.12 & 195 & \multirow{11}{*}{$\begin{aligned} \mathrm{T} & =1.684 \\
\mathrm{P} & =01587\end{aligned}$} \\
\hline Pulses & 31 & 45 & \\
\hline Egg & 50 & 75 & \\
\hline $\begin{array}{l}\text { Meat,chicken or } \\
\text { fish }\end{array}$ & 75 & 75 & \\
\hline $\begin{array}{c}\text { Milk \&milk } \\
\text { product }\end{array}$ & 395 & 500 & \\
\hline Roots \&tubers & 69.75 & 87.5 & \\
\hline $\begin{array}{c}\text { Green leafy } \\
\text { vegetable }\end{array}$ & 61.75 & 75 & \\
\hline Other vegetable & 93.5 & 125 & \\
\hline Fruits & 94 & 100 & \\
\hline Sugar & 17.87 & 21.25 & \\
\hline Fats \& oil & 18.87 & 25 & \\
\hline
\end{tabular}


Other vegetables mean range is 93.5 and $\mathrm{RDA}$ is 125 ,fruits mean range is 94 and RDA is 100,sugar intake is 17.87 and RDA is 21.25 and fats and oil intake is 18.87 and RDA is 25. Calculated value of food groups are -112.02 and tabulated value is 1.684 . It concludes that mean dietary intake is lower than RDA.

Table 3: Age and gender wise pre Anthropometric characteristics of children's (EXP GP)

\begin{tabular}{|c|c|c|c|}
\hline Age groups & $\begin{array}{c}\text { (6Months- } \\
\text { 3) } \\
\text { Yrs }\end{array}$ & $\begin{array}{c}(4-7) \\
\text { Yrs }\end{array}$ & $\begin{array}{l}(8-10) \\
\text { Yrs }\end{array}$ \\
\hline Height (cms) & 82 & 107 & 134 \\
\hline $\begin{array}{c}\text { Standard Height } \\
(\mathrm{cms})\end{array}$ & 88.9 & 109 & 134.62 \\
\hline$t=$ & 1.729 & 1.729 & 1.729 \\
\hline $\mathrm{P}=$ & $(0.0000)$ & $(0.0165)$ & - \\
\hline Weight (cms) & 9.3 & 14.32 & 25.38 \\
\hline $\begin{array}{l}\text { Standard Weight } \\
(\mathrm{cms})\end{array}$ & 16 & 27.5 & 44.7 \\
\hline$t=$ & 1.729 & 1.729 & 1.729 \\
\hline $\mathrm{P}=$ & 0.47730 & 0.007 & 0.0116 \\
\hline Head circumference & 45 & 48.4 & 51.57 \\
\hline $\begin{array}{c}\text { Standard Head } \\
\text { circumference }(\mathrm{cms})\end{array}$ & 47.5 & 50 & 52.5 \\
\hline$t=$ & 1.729 & 1.729 & 1.729 \\
\hline $\mathrm{P}=$ & 0.5000 & 0.1949 & 0.0012 \\
\hline Arm circumference & 12.9 & 16.1 & 19.58 \\
\hline $\begin{array}{c}\text { Standard Arm } \\
\text { circumference }(\mathrm{cms})\end{array}$ & 17 & 20.5 & 23 \\
\hline$t=$ & $1.729(-)$ & $1.729(-)$ & $\begin{array}{c}1.729(0.00 \\
0)\end{array}$ \\
\hline
\end{tabular}

Above table are mentioned age and gender wise preAnthropometric characteristics of children is analysed in the age group of 6 Months to 10 years old. Mean Height of 6 months- 3 year old subjects are found to be 82 and standard height is 88.9, weight is calculated 9.3 and standard weight is $16 \mathrm{~kg}$, head circumference is 45 and standard value is 47.5 and arm circumference is 12.9 and standard value is 17.subject age group 4-7 years value were found height - 107 and standard value is $109 \mathrm{~cm}$, weight 9.3 and standard value is $16 \mathrm{~kg}$, head circumference is 45 and standard value is $47.5 \mathrm{~cm}$, arm circumference is 12.9 and standard value is $17 \mathrm{~cm}$. subject group $8-10$ years value were found height- 134 and standard value is 134.62 , weight- 25.38 and standard value is 44.7, head circumference- 51.57 and standard value is 52.5, arm circumference -19.58 and standard value is $23 \mathrm{~cm}$.
Table 4: Age and gender wise post Anthropometric characteristics of children's (EXPERIMENTAL GP)

\begin{tabular}{|c|c|c|c|}
\hline Parameter & $\begin{array}{c}\text { (6month-3) } \\
\text { Yrs }\end{array}$ & $\begin{array}{c}(4-7) \\
\text { Yrs }\end{array}$ & $\begin{array}{c}(8- \\
10) \\
\text { Yrs }\end{array}$ \\
\hline Height $(\mathrm{cms})$ & 82.3 & 106.1 & 133.1 \\
\hline Standard Height $(\mathrm{cms})$ & 88.9 & 109 & 134.62 \\
\hline $\mathrm{T}=$ & 1.729 & 1.729 & 1.729 \\
\hline $\mathrm{P}=$ & 0.4262 & 0.0094 & 0.0115 \\
\hline Weight (cms) & 10 & 15.58 & 26.39 \\
\hline Standard Weight $(\mathrm{cms})$ & 16 & 27.5 & 44.7 \\
\hline $\mathrm{T}=$ & 1.729 & 1.729 & 1.729 \\
\hline $\mathrm{P}=$ & 0.000 & - & - \\
\hline Head circumference & 45 & 48.4 & 51.57 \\
\hline $\begin{array}{c}\text { Standard Head } \\
\text { circumference }(\mathrm{cms})\end{array}$ & 47.5 & 50 & 52.5 \\
\hline $\mathrm{T}=$ & 1.729 & 1.729 & 1.729 \\
\hline $\mathrm{P}=$ & 0.0000 & 0.004 & 0.009 \\
\hline Arm circumference & 13.1 & 16.7 & 21 \\
\hline $\begin{array}{c}\text { Standard Arm } \\
\text { circumference }(\mathrm{cms})\end{array}$ & 17 & 20.5 & 23 \\
\hline $\mathrm{T}=$ & 1.729 & 1.729 & 1.729 \\
\hline $\mathrm{P}=$ & 0.1261 & 0.3446 & 0.5000 \\
\hline
\end{tabular}

Table 4 noted that the age and gender wise post anthropometric characteristics of children in age group of 6 Months -10 years old children.

The calculated value of height in experimental group is 2.35 and tabulated value is 1.729 for $19 \%$ of freedom for $5 \%$ level of significance. The calculated value of weight is -4.24 and tabulated value is 1.729 , the calculated value of head circumference is -0.86 and tabulated value is 1.729 and the calculated value of arm circumference is -5.66 and tabulated value is 1.729 . It was concluding that the nutriaspro powder is effective on subjects to increased height, weight, arm circumference of children's and shown effect on overall growth. Nutritional supplementation and child health programmes, which are currently focused on impoverished rural areas, should not exclude informal settlements (Beatrice Olack 2011). Table 5 was denoted that the age and gender wise pre anthropometric characteristics of children in age group of 6 Months to 10 years old in control group. 


\begin{tabular}{|c|c|c|c|}
\hline$\underbrace{\text { Age groups }}_{\text {Parameter }}$ & $\begin{array}{c}\text { (6Months- } \\
\text { 3) } \\
\text { Yrs }\end{array}$ & $\begin{array}{c}(4-7) \\
\text { Yrs }\end{array}$ & $\begin{array}{c}(8-10) \\
\text { Yrs }\end{array}$ \\
\hline Height (cms) & 87.5 & 102.5 & 133.6 \\
\hline Standard Height (cms) & 88.9 & 109 & 134.62 \\
\hline $\mathrm{T}=$ & 1.729 & 1.729 & 1.729 \\
\hline $\mathrm{P}=$ & 0.5000 & - & 0.0301 \\
\hline Weight (cms) & 12.5 & 17 & 25.6 \\
\hline Standard Weight $(\mathrm{cms})$ & 16 & 27.5 & 44.7 \\
\hline $\mathrm{T}=$ & 1.729 & 1.729 & 1.729 \\
\hline $\mathrm{P}=$ & - & 0.000 & 0.5000 \\
\hline Head circumference & 47 & 49.29 & 51.57 \\
\hline $\begin{array}{c}\text { Standard Head } \\
\text { circumference }(\mathrm{cms})\end{array}$ & 47.5 & 50 & 52.5 \\
\hline $\mathrm{T}=$ & 1.729 & 1.729 & 1.729 \\
\hline $\mathrm{P}=$ & 0.500 & 0.030 & 0.003 \\
\hline Arm circumference & 12.9 & 16.75 & 22 \\
\hline $\begin{array}{c}\text { Standard Arm } \\
\text { circumference }(\mathrm{cms})\end{array}$ & 17 & 20.5 & 23 \\
\hline $\mathrm{T}=$ & 1.729 & 1.729 & 1.729 \\
\hline $\mathrm{P}=$ & - & 0.000 & 0.002 \\
\hline
\end{tabular}

Table 5: Age and gender wise pre Anthropometric characteristics of children's (EXP GP)

Table 6 was explain that the age and gender wise post anthropometric characteristics of children in age group of 6 Months -10 years old in control group Mean Height of 6 months- 3 year old subjects are found to be 82 and standard height is 88.9 , weight is calculated 12.85 and standard weight is $16 \mathrm{~kg}$, head circumference is 47 and standard value is 48 and arm circumference is 13.05 and standard value is 17.subject age group 4-7 years value were found height - 106.1 and standard value is $109 \mathrm{~cm}$, weight -17.5 and standard value is $27.5 \mathrm{~kg}$, head circumference is 48.4 and standard value is $50 \mathrm{~cm}$, arm circumference is 17.2 and standard value is $20.5 \mathrm{~cm}$. subject group $8-10$ years value were found height- 133 and standard value is 134.62, weight- 26.20 and standard value is 44.7 , head circumference- 51.57 and standard value is 52.5, arm circumference -22 and standard value is $23 \mathrm{~cm}$. It was shown that there is a lots difference in all parameters of anthropometry.
Table 6: Age and gender wise post Anthropometric characteristics of children's (Control GP)

\begin{tabular}{|c|c|c|c|}
\hline Age groups & $\begin{array}{c}\text { (6month- } \\
\text { 3) } \\
\text { Yrs }\end{array}$ & $\begin{array}{c}(4-7) \\
\text { Yrs }\end{array}$ & $\begin{array}{c}\text { (8-10) } \\
\text { Yrs }\end{array}$ \\
\hline Height (cms) & 82.3 & 106.1 & 133.1 \\
\hline Standard Height (cms) & 88.9 & 109 & 134.62 \\
\hline $\mathrm{T}=$ & 1.729 & 1.729 & 1.729 \\
\hline $\mathrm{P}=$ & - & - & 0.729 \\
\hline Weight (cms) & 12.85 & 17.5 & 26.20 \\
\hline Standard Weight $(\mathrm{cms})$ & 16 & 27.5 & 44.7 \\
\hline $\mathrm{T}=$ & 1.729 & 1.729 & 1.729 \\
\hline $\mathrm{P}=$ & 0.000 & 0.000 & - \\
\hline Head circumference & 47 & 48.4 & 51.57 \\
\hline $\begin{array}{c}\text { Standard Head } \\
\text { circumference }(\mathrm{cms})\end{array}$ & 48 & 50 & 52.5 \\
\hline $\mathrm{T}=$ & 2.353 & 1.729 & 1.729 \\
\hline $\mathrm{P}=$ & 0.5000 & 0.0304 & 0.0003 \\
\hline Arm circumference & 13.05 & 17.2 & 22 \\
\hline $\begin{array}{c}\text { Standard Arm } \\
\text { circumference }(\mathrm{cms})\end{array}$ & 17 & 20.5 & 23 \\
\hline $\mathrm{T}=$ & 1.729 & 1.729 & 1.729 \\
\hline $\mathrm{P}=$ & 0.0281 & 0.000 & - \\
\hline
\end{tabular}

\section{Conclusion}

According to the findings in this study, malnutrition is highly prevalent in the all socioeconomic group's children's. There are many reasons as to why the prevalence is evident and will continue in that some factors such as low levels of maternal education, knowledge of nutrition and proper cooking methods and influence a lot on food choices for child feeding. There is little surveillance and the trained personnel are less motivated due to poor facilitation and issues of early warning systems are not well addressed. It was concluded that nutri-spro powder was shown effective changes on overall growth and development of children because it was observed that the Stunting is the predominant nutritional problem, and the elevated prevalence in older children indicates failure in growth and development during the first two years of life so mothers can used as a weaning food also and it may be effective if the expecting mothers if she was introduced in her diet from second trimester possibly it may be lower the risk of low birth weight babies.

\section{References}

[1] World Health Organization, United Nations Global Status Report on Violence Prevention 2014. Geneva, Switzerland: WHO Press; 2014. 
[2] Anuradha $\mathrm{R}^{1}$ Ranjit Sivanandham, ${ }^{2}$ Sam Dashni Salome, ${ }^{3}$ Roniya Francis, ${ }^{4}$ Roopa D, ${ }^{5}$ Sakthi Sampavi, ${ }^{6}$ Sabu S R, ${ }^{7}$ and Ranjit Prasad (2014)Nutritional Status of Children Aged 3-6 Years in a Rural Area of TamilnaduJ Clin Diagn Res. 2014 Oct; 8(10): JC01-JC04. Published online 2014 Oct 20. doi: 10.7860/JCDR/2014/8902.4969

[3] Gopalan, C., Swaminathan, M. C., Kumari, V.K.K., Rao, D. H. \&Vijayaraghavan, K. (1973) Effect of calorie supplementation on growth of undernourished children. Am. J. Clin. Nutr. 26: 563-566.

[4] Lutter, C. K., Mora, J. O., Habicht, J. -P.Rasmussen, K. M., Robson, D. S. \& Herrera, M. G. (1990) Age-specific responsiveness of weight and length to nutritional supplementation.
Am. J. Clin. Nutr. 51: $\quad 359-364$.

[5] Beatrice Olack,Heather Burke, Leonard Cosmas, Sapna Bamrah, Kathleen Dooling, Daniel R. Feikin,Leisel E. Talley, and Robert F. Breiman(2011) Nutritional Status of Underfive Children Living in an Informal Urban Settlement in Nairobi, Kenya J Health Popul Nutr. 2011 Aug; 29(4): 357-363.

[6] Mirjana Gurinović, in Reference Module in Food Science, 2016 Nutrition Epidemiology and Public Health Nutrition.

[7] Willett, W., 2013. Nutritional Epidemiology, third ed., vol. 40. Oxford University Press, New York, USA. 